\title{
ASSOCIATION OF THYROID FUNCTION WITH BMI, BODY FAT \% AND VISCERAL FAT LEVEL IN HEALTHY EUTHYROID INDIVIDUALS
}

\author{
Yumnam Anjana Devi' ${ }^{1}$ Keisam Reetu Devi², Avinash Keisam³ ${ }^{3}$ Sangeeta Mayanglambam ${ }^{4}$
}

${ }_{1}^{1}$ Associate Professor, Department of Physiology, JNIMS, Imphal, Manipur, India.

${ }^{2}$ Assistant Professor, Department of Physiology, JNIMS, Imphal, Manipur, India.

${ }^{3}$ Assistant Professor, Department of Community Medicine, JNIMS, Imphal, Manipur, India.

${ }^{4}$ Demonstrator, Department of Physiology, JNIMS, Imphal, Manipur, India.

\section{BACKGROUND}

ABSTRACT

Obesity is known to be associated with altered thyroid function, increased risk of cardiovascular diseases, diabetes, insulin resistance and metabolic disorders. Thyroid hormones affect body weight through modification of basal metabolic rate.

The study aims to assess the BMI and correlate with TSH, f T3, f T4, body fat \% and visceral fat level in healthy euthyroid individuals to see if any association between obesity and thyroid status exists.

\section{MATERIALS AND METHODS}

This study was conducted on 92 healthy volunteers amongst the staffs of Jawaharlal Nehru Institute of Medical Sciences (JNIMS), Imphal, Manipur. Anthropometric measurements were done and Body Mass Index (BMI) was calculated. Thyroid Stimulating Hormone (TSH), f T3 and f T4 levels were measured by using chemiluminescent immunoassay and subjects with TSH value between 0.3 - $3.6 \mathrm{mIU} / \mathrm{L}$ were taken for the study. Body fat \% and visceral fat level were measured by Bioelectrical Impedance (BI) method by using OMRON-HBF-212 (Body Composition Monitor). Data was analysed using SPSS version 22. The association between variables was determined using ANOVA.

\section{RESULTS}

The study showed significant association of TSH $(p=0.025)$, body fat $\%(p=0.000)$ and visceral fat level $(p=0.000)$ with BMI. There was no statistically significant association between body fat $\%$ and TSH, f T3, f T4. There was significant association between visceral fat level and $\mathrm{f} \mathrm{T3}$.

\section{CONCLUSION}

Serum TSH level increases with increase in fat content of the body, even if the upper limit of TSH is within normal limits. This increased level of body fat $\%$ and visceral fat level in obese euthyroid individuals may lead to increased risk for development of obesity related common health problems, thus arising the need to keep the body weight, body fat \% and visceral fat level at an acceptable level.

\section{KEY WORDS}

TSH, BMI, Body Fat \%, Visceral Fat Level, Euthyroid.

HOW TO CITE THIS ARTICLE: Devi YA, Devi KR, Keisam A, et al. Association of thyroid function with BMI, body fat \% and visceral fat level in healthy euthyroid individuals. J. Evolution Med. Dent. Sci. 2018;7(29):3270-3274, DOI: 10.14260/jemds/2018/737

\section{BACKGROUND}

Obesity is a condition in which excess body fat has accumulated to the extent that it may have a negative effect on health leading to a reduced life expectancy and increased health problems. It may be associated with various health problems including cardiovascular disease, diabetes, insulin resistance and metabolic disorders. ${ }^{1}$

Metabolic syndrome is an important predictor of cardiovascular risk and is a cluster of abnormalities such as abdominal obesity, dyslipidaemia, high plasma glucose and hypertension. Thyroid hormones are known to have a variety of effects on metabolic syndrome determinants and studies

'Financial or Other Competing Interest': None.

Submission 26-06-2018, Peer Review 08-07-2018,

Acceptance 11-07-2018, Published 16-07-2018.

Corresponding Author:

Keisam Reetu Devi,

Assistant Professor

Department of Physiology,

JNIMS, Imphal, Porompat-795005,

Manipur, India.

E-mail: keisamreetu@yahoo.co.in

DOI: $10.14260 /$ jemds/2018/737 have shown association between thyroid hormone levels and metabolic syndrome in euthyroid patients, though conflicting results are there which may be due to ethnic variation apart from other factors. 2,3

Body composition and thyroid hormones appear to be closely related as thyroid hormones is known to be involved in the regulation of basal metabolism and thermogenesis, playing an important role in lipid and glucose metabolism, food intake and fat oxidation. 4

The relation between thyroid function and weight might also be of importance, as overweight is associated with increased morbidity and disability. Studies have found significant association of TSH within the normal reference range with body weight. ${ }^{5}$ Body Mass Index (BMI) is a very relevant parameter to decide if a person is obese.

Weight change is largely due to an imbalance in energy intake and expenditure. It is also well recognised as common manifestation of overt thyroid dysfunction, as thyroid hormones are known to regulate the resting energy expenditure. The potential mechanism underlying the association between body fat \%, visceral fat level and thyroid function are less clear among euthyroid individuals, in whom it is possible that weight change could precede subsequent 
changes in thyroid hormone T3, T4 and TSH levels. It is not clear whether obesity per se may influence thyroid function or if small differences in thyroid function within the normal range might play a role in modulating weight.

Studies are needed to evaluate whether subclinically low thyroid function, even those in normal serum TSH concentration range can cause obesity and increase cardiovascular risks.

The present study aims to assess the BMI and correlate with TSH, f T3, f T4, body fat \%, visceral fat level in healthy euthyroid individuals to see if any association between obesity and thyroid status exists.

\section{MATERIALS AND METHODS}

This cross-sectional study was conducted at Jawaharlal Nehru Institute of Medical Sciences (JNIMS), Imphal, Manipur. A total of 100 healthy volunteers were screened among the staffs of JNIMS.

Healthy adults without any self-reported thyroid disease or any treatment related with thyroid, in the age group of 2035 years were screened from among the staffs of JNIMS.

Subjects with any H/O thyroid disease (past or present), cigarette smokers, subject with chronic liver disease, renal disease, pregnancy, congestive heart disease, malnutrition or malignant disease or those taking drugs that may affect thyroid functions (Lithium, amiodarone, steroids, beta blockers, interferon) and subjects using drugs which may affect body water-lipid, homeostasis like diuretics or oral contraceptives were excluded from the study.

An informed written consent was obtained from all the subjects after the objectives and procedure of the study was explained to them. The study was approved by the Ethical Committee of the institute.

Weight was measured by using a standard weighing machine without shoes to the nearest $0.5 \mathrm{~kg}$ and height was measured by using a height meter without shoes to the nearest $0.5 \mathrm{~cm}$. Body Mass Index (BMI) was calculated using Quetelet index and WHO classification ${ }^{6}$ was used for interpretation of the findings.

\section{Subjects were classified according to their Body Mass Index (BMI) as-}

1. Underweight: $<18.5 \mathrm{~kg} / \mathrm{m}^{2}$

2. Normal weight: $18.5-24.9 \mathrm{~kg} / \mathrm{m}^{2}$

3. Overweight: $25-29.9 \mathrm{~kg} / \mathrm{m}^{2}$

4. Obese: $\geq 30 \mathrm{~kg} / \mathrm{m}^{2}$

TSH, f T3 and f T4 levels were measured by using chemiluminescent immunoassay and subjects with TSH value between 0.3 - $3.6 \mathrm{mIU} / \mathrm{L}$ were taken for the study. Eight (8) subjects whose TSH is more than $3.6 \mathrm{mIU} / \mathrm{L}$ were excluded from the study.

Body fat $\%$ and visceral fat level were measured by Bioelectrical Impedance (BI) method by using Omron-HBF212 (Body Composition Monitor) with each subject in a standing position without shoes, wearing light clothes. The obesity classification value advocated by Lohman (in 1986) and Nagamine (in 1972) is used as reference.

\begin{tabular}{|c|c|c|}
\hline Body Fat \% Classification & Male & Female \\
\hline -(Low) & 5.0 to $9.9 \%$ & 5.0 to $19.9 \%$ \\
\hline 0(Normal) & 10.0 to $19.9 \%$ & 20.0 to $29.9 \%$ \\
\hline+ (High) & 20.0 to $24.9 \%$ & 30.0 to $34.9 \%$ \\
\hline++ (Very High) & $25.0 \%$ to & $35.0 \%$ to \\
\hline
\end{tabular}

According to Omron Healthcare Figures

\begin{tabular}{|c|c|}
\hline Level Classification & Visceral Fat Level \\
\hline 0 (Normal) & 1 to 9 \\
\hline+ (High) & 10 to 14 \\
\hline++ (Very High) & 15 to 30 \\
\hline
\end{tabular}

\section{Statistical Analysis}

Data was analysed using SPSS version 22. The association between variables was determined using ANOVA. P value less than 0.05 was considered statistically significant.

\section{RESULTS}

A total of 100 subjects were screened among the staffs of JNIMS and 8 were excluded from the study as their TSH values were more than $3.6 \mathrm{mIU} / \mathrm{L}$

In the present study, 92 subjects with mean age of $27.83 \pm 8.70$ years including 54 males with mean age of $26.52 \pm 7.88$ years and 38 females with mean age of $29.68 \pm 9.56$ years were recruited.

The mean value of the various variables assessed is shown in Table 1. As shown in Table 2 most of the participants $38(41.3 \%)$ were overweight, while $8(8.70 \%)$ were obese.

As shown in Table 3, there was significant association between BMI and serum TSH, body fat \% and visceral fat level. The mean value of TSH, body fat $\%$ and visceral fat level were higher in those subjects who were overweight and obese.

In the present study, among the subjects, body Fat $\%$ of $44(47.83 \%)$ were in the category of very high body fat $\%, 16$ (17.39\%) had high, while $28(30.43 \%)$ had normal body fat $\%$. Only 4 (4.35\%) had low level of body fat $\%$.

As shown in Table 5, there was significant association between various grades of visceral fat level with $\mathrm{f}$ T3. Among the subjects, $6(6.52 \%)$ had very high level of visceral fat, while 24 (26.09\%) had high level of visceral fat. 62 (67.39\%) subjects had normal visceral fat level.

Our study showed significant association of $\mathrm{TSH}$ $(p=0.025)$, body fat $\%(p=0.000)$ and visceral fat level $(p=0.000)$ with BMI. There was no statistically significant association between body fat $\%$ and TSH, f T3 and f T4. There was significant association between visceral fat level and $\mathrm{f} T 3$.

\begin{tabular}{|c|c|c|c|}
\hline & Total (n=92) & Males (n=54) & Females (n=38) \\
\hline Age & $27.83 \pm 8.7$ & $26.52 \pm 7.88$ & $29.68 \pm 9.56$ \\
\hline BMI & $24.28 \pm 4.66$ & $25.15 \pm 5.20$ & $23.05 \pm 3.50$ \\
\hline TSH (mIU/L) & $2.44 \pm 1.38$ & $2.77 \pm 1.46$ & $1.96 \pm 1.12$ \\
\hline $\begin{array}{c}\text { F T3 } \\
\text { pmol/L) }\end{array}$ & $2.69 \pm 0.73$ & $2.67 \pm 0.82$ & $2.71 \pm 0.58$ \\
\hline $\begin{array}{c}\text { F T4 } \\
\text { pmol/L) }\end{array}$ & $1.76 \pm 2.14$ & $1.55 \pm 1.57$ & $2.06 \pm 2.77$ \\
\hline Body Fat \% & $29.17 \pm 9.18$ & $27.74 \pm 10.76$ & $31.19 \pm 5.86$ \\
\hline $\begin{array}{c}\text { Visceral Fat } \\
\text { Level }\end{array}$ & $7.78 \pm 5.20$ & $8.93 \pm 6.08$ & $6.16 \pm 3.00$ \\
\hline \multicolumn{4}{|c|}{ Table 1. Distribution of variables among the } \\
Study Subjects (Mean \pm SD) \\
\hline \multicolumn{4}{|c|}{} \\
\hline
\end{tabular}




\begin{tabular}{|c|c|c|c|}
\hline Grades of BMI & $\begin{array}{c}\text { Total } \\
(\mathbf{n = 9 2})\end{array}$ & $\begin{array}{c}\text { Males } \\
(\mathbf{n = 5 4 )}\end{array}$ & $\begin{array}{c}\text { Females } \\
(\mathbf{n = 3 8})\end{array}$ \\
\hline $\begin{array}{c}\text { Underweight: }<18.5 \\
\mathrm{~kg} / \mathrm{m}^{2}\end{array}$ & $\begin{array}{c}12 \\
(13.04 \%)\end{array}$ & $8(14.81 \%)$ & $4(10.53 \%)$ \\
\hline $\begin{array}{c}\text { Normal weight: } \\
18.5-24.9 \mathrm{~kg} / \mathrm{m}^{2}\end{array}$ & $\begin{array}{c}34 \\
(36.96 \%)\end{array}$ & $16(29.63 \%)$ & $18(47.37 \%)$ \\
\hline $\begin{array}{c}\text { Overweight: } 25-29.9 \\
\mathrm{~kg} / \mathrm{m}^{2}\end{array}$ & $\begin{array}{c}38 \\
(41.30 \%)\end{array}$ & $22(40.74 \%)$ & $16(42.11 \%)$ \\
\hline Obese: $\geq 30 \mathrm{~kg} / \mathrm{m}^{2}$ & $8(8.70 \%)$ & $8(14.81 \%)$ & $0(0 \%)$ \\
\hline Table 2. Distribution of Subjects according to Grades of \\
Body Mass Index (BMI) \\
\hline
\end{tabular}

\begin{tabular}{|c|c|c|c|c|c|}
\hline Variable & $\begin{array}{c}\text { Underweig } \\
\text { ht }(n=12)\end{array}$ & $\begin{array}{c}\text { Normal } \\
(n=34)\end{array}$ & $\begin{array}{l}\text { Overweig } \\
\text { ht }(n=38)\end{array}$ & $\begin{array}{l}\text { Obese } \\
(n=8)\end{array}$ & $P$ value \\
\hline $\begin{array}{c}\mathrm{TSH} \\
(\mathrm{mIU} / \mathrm{L})\end{array}$ & $2.60 \pm 0.82$ & $1.99 \pm 0.90$ & $2.55 \pm 1.70$ & $3.55 \pm 1.49$ & $0.025^{*}$ \\
\hline $\begin{array}{c}\mathrm{fT3} \\
(\mathrm{pmol} / \mathrm{L} \\
\text { ) }\end{array}$ & $2.93 \pm 0.30$ & $2.71 \pm 0.53$ & $2.71 \pm 0.91$ & $2.10 \pm 0.71$ & 0.081 \\
\hline $\begin{array}{c}\mathrm{fT} 4 \\
(\mathrm{pmol} / \mathrm{L} \\
)\end{array}$ & $1.17 \pm 0.16$ & $1.19 \pm 0.68$ & $2.38 \pm 3.10$ & $2.12 \pm 1.06$ & 0.078 \\
\hline $\begin{array}{l}\text { Body } \\
\text { Fat } \%\end{array}$ & $14.75 \pm 4.80$ & \begin{tabular}{|c|}
$25.65 \pm 5.2$ \\
2
\end{tabular} & $\begin{array}{c}34.02 \pm 5.7 \\
5\end{array}$ & $\begin{array}{c}42.70 \pm 1.8 \\
9\end{array}$ & $\begin{array}{c}0.000^{* *} \\
*\end{array}$ \\
\hline $\begin{array}{c}\text { Visceral } \\
\text { Fat } \\
\text { Level }\end{array}$ & $2.17 \pm 1.40$ & $4.47 \pm 1.16$ & $9.95 \pm 1.86$ & $20.0 \pm 4.59$ & $\begin{array}{c}0.000^{* *} \\
*\end{array}$ \\
\hline $\begin{array}{l}\text { Table } 3 \\
\text { Fat \% }\end{array}$ & ccociatio & ol & BMI and & jects ( & $\begin{array}{l}\text { Body } \\
n \pm S D)\end{array}$ \\
\hline
\end{tabular}

${ }^{*} \mathrm{p}<0.05,{ }^{* * *} \mathrm{p}<0.001$

\begin{tabular}{|c|c|c|c|c|c|c|}
\hline \multirow[b]{2}{*}{$\begin{array}{l}\text { Body } \\
\text { Fat } \%\end{array}$} & \multicolumn{2}{|c|}{ TSH } & \multicolumn{2}{|c|}{ f T3 } & \multicolumn{2}{|c|}{ fT4 } \\
\hline & $\begin{array}{c}\text { Male } \\
(n=54)\end{array}$ & $\begin{array}{l}\text { Female } \\
(\mathrm{n}=38)\end{array}$ & $\begin{array}{c}\text { Male } \\
(n=54)\end{array}$ & $\begin{array}{l}\text { Female } \\
(n=38)\end{array}$ & $\begin{array}{c}\text { Male } \\
(n=54)\end{array}$ & $\begin{array}{l}\text { Female } \\
(n=38)\end{array}$ \\
\hline \multirow{2}{*}{ Low } & $2.50 \pm$ & & $2.70 \pm$ & & & \\
\hline & 0 & & & & & \\
\hline \multirow{2}{*}{ Normal } & 2.20 & & $3.02 \pm$ & & & \\
\hline & 1.01 & & 0.37 & & 0.0 & \\
\hline \multirow{2}{*}{ High } & $2.10 \pm$ & $2.37 \pm$ & $2.98 \pm$ & $2.67 \pm$ & $0.94 \pm$ & $1.80 \pm$ \\
\hline & 0.36 & 0.72 & 0.29 & & 0.22 & \\
\hline Very & $3.25 \pm$ & $2.01 \pm$ & $2.43 \pm$ & $2.73 \pm$ & $1.97 \pm$ & $3.57 \pm$ \\
\hline & & & & & 2.01 & \\
\hline$P$ value & 0.062 & 0.389 & 0.099 & 0.902 & 0.168 & 0.064 \\
\hline \multicolumn{7}{|c|}{$\begin{array}{c}\text { Table 4. Association of different grades of Body Fat \% } \\
\text { with TSH, } f \text { T3, f T4 }\end{array}$} \\
\hline
\end{tabular}

\begin{tabular}{|c|c|c|c|}
\hline $\begin{array}{c}\text { Visceral Fat } \\
\text { Level }\end{array}$ & TSH & f T3 & f T4 \\
\hline Normal & $2.25 \pm 1.46$ & $2.69 \pm 0.72$ & $1.57 \pm 1.43$ \\
\hline High & $2.79 \pm 1.14$ & $2.87 \pm 0.65$ & $2.06 \pm 3.44$ \\
\hline Very High & $2.97 \pm 1.22$ & $1.90 \pm 0.72$ & $2.53 \pm 1.74$ \\
\hline P value & 0.168 & $0.013^{*}$ & 0.428 \\
\hline \multicolumn{4}{|c|}{ Table 5. Association of Visceral Fat Level and } \\
TSH, f T3, f T4 (Both Sex) \\
\hline
\end{tabular}

$* \mathrm{p}<0.05$

\section{DISCUSSION}

In the present study there was significant association between BMI and TSH $(p=0.025)$, body fat $\%(p=0.000)$ and visceral fat level $(\mathrm{p}=0.000)$.

Similar to our findings, studies have found that mean TSH serum levels increased with increasing BMI and there is an inverse correlation between free thyroxine (fT4) values and
Body Mass Index (BMI), even when fT4 values remain in normal range. They found no association between BMI and serum f T3.7,8 Other studies also found significant relationship between TSH and increasing BMI.5,9-11

This association between TSH and BMI was thought to be due to influence of adipose tissue signals and leptin may have significant effects on central regulation of thyroid function through TRH.12 The synthesis of TSH and thyroid hormones may be affected by adipose tissue and calorie intake. The mechanism for such a relation would be related to secretion of leptin by adipose tissue.13 The level of leptin is directly correlated to the amount of adipose tissue and leptin has been reported to stimulate the biosynthesis of TSH in vitro. ${ }^{14}$ The increased blood concentration of TSH may be the high levels of leptin found in obese subjects. 15

Studies have revealed that fat cells and precursor forms have receptors for TSH and TSH may directly stimulate the production of leptin by adipocytes. ${ }^{16}$ Association between TSH concentration and BMI is stronger in severely obese participants than in mildly obese participants. ${ }^{17}$

Contrary to our findings, studies found no evidence of association between TSH within the normal range and BMI. ${ }^{18-20}$

Body fat \% refers to the amount of body fat mass in regard to the total body weight expressed as percentage. In the present study, there was no significant association between Body Fat\%, TSH, f T3 and f T4. Similar to our study, Kok et al 2005 found no significant correlation between TSH and percentage total body fat and visceral and subcutaneous fat. ${ }^{21}$ Teixeira et al 2009 observed that BMI, Body Fat \%, waist circumference and fat mass index were not correlated with TSH. ${ }^{22}$ Choi et al 2008 in their study found no significant correlation between TSH level and BMI or Fat \%.23

Contrary to our study, Pinkney JH et al 1998 in their study found correlation between plasma TSH levels and percentage of body fat. ${ }^{24}$ Ortiga et al 2007 found plasma TSH concentration positively associated with body weight and percentage body fat. ${ }^{25}$ Galofre et al 2008 also found positive correlation between TSH and body fat \%. ${ }^{17}$

Zhang J et al 2012 in their study found that serum TSH in normal range is significantly correlated with BMI and percentage of body fat in females. ${ }^{26}$ Sanhita et al 2015 found that serum TSH level increases with increase in fat content of the body. Obese women shows higher serum TSH level even if the upper limit of TSH is within normal limit. ${ }^{27}$ The positive correlation between TSH and $\mathrm{BF} \%$ may be due to increased concentration of leptin and pro-opiomelanocortin in obese patients which stimulate Thyrotropin Releasing Hormone (TRH) neurons in the paraventricular nucleus leading to an increment in TSH. ${ }^{24,28}$ TSH can directly stimulate leptin secretion by adipocytes. 16 The presence of TSH receptors in adipose tissue causes proliferation of adipose tissue and differentiation of preadipocytes into adipocytes. ${ }^{29,30}$ Higher levels of leptin are proportional to overall fat percentage and some studies have shown a positive correlation with TSH levels. ${ }^{24,31}$

In the present study among the subjects $6(6.52 \%)$ had very high level of visceral fat, while $24(26.09 \%)$ had high level of visceral fat. This high level of visceral fat is thought to be closely linked to increased levels of fat in bloodstream, which can lead to hyperlipidaemia and diabetes. Visceral adiposity is associated with cardiovascular risk factors and 
increased cardiovascular risk. Our study showed significant association between $\mathrm{f}$ T3 and visceral fat level and also between BMI and visceral fat level. There is increased visceral fat level in overweight and obese subjects. Studies have shown that triiodothyronine controls metabolic and energy homeostasis and thus influences body weight and TSH via receptors in fat tissues inducing differentiation of preadipocytes to adipocytes and expansion of adipose tissue. ${ }^{32}$ Thyroxine promotes protein synthesis and growth and also helps to regulate the body's metabolism. Studies found reduced gene expression of TSH and $\mathrm{f}$ T3 receptors in both subcutaneous and visceral fat in obese subjects. They thought that the increase in plasma TSH and f T3 in obesity may be an attempt to cope with the peripheral resistance as a consequence of the hypertrophy changes of adipocytes. ${ }^{33}$ They also reported that obesity may play an important role in modifying the thyroid hormones and TSH receptor gene expression in both subcutaneous and visceral adipose tissue. Waist circumference is more closely associated with visceral fat than BMI and another study reported that the TSH concentration is associated with the amount of subcutaneous but not preperitoneal fat indicating that serum TSH concentration may have a more marked effect on total body fat than on visceral fat. ${ }^{20}$

Visceral Abdominal Adipose Tissue (VAAT) surrounds the internal organs and increased levels of VAAT are more significant than increased levels of subcutaneous fat in terms of the risk of metabolic syndrome, insulin resistance and cardiovascular mortality. ${ }^{34} \mathrm{An}$ association between high level TSH and increased VAT (visceral adipose tissue) thickness has been demonstrated. This association between TSH levels and VAT may be the cause for increased cardiovascular risk associated with elevated TSH plasma concentration within the normal range. 35 Giovanna Muscogiuri 2012 et al found strong correlation between thyroid function and abdominal adipose tissue in particular with visceral adipose tissue. ${ }^{36}$ Visceral fat is body fat that is stored within the abdominal cavity and is therefore stored around a number of important internal organs such as the liver, pancreas and intestines. Visceral fat is sometimes referred to as 'active fat,' because research has shown that this type of fat plays a distinctive and potentially dangerous role affecting how our hormones function and is associated with increased risks of a number of health problems such as diabetes, hyperlipidaemia and cardiovascular diseases.

\section{CONCLUSION}

In the present study, significant correlation was found between BMI and TSH, fT3, fT4, body fat $\%$ and visceral fat level. There is an increase in body fat $\%$ and visceral fat level, even if the TSH is within normal limits. This increased level may lead to increased risk for development of obesity related health problems even in euthyroid individuals. It is therefore important to keep the body weight, body fat \% and visceral fat level at acceptable levels to prevent or improve conditions of common diseases.

\section{REFERENCES}

[1] Haslam DW, James WPT. Obesity. The Lancet 2005;366(9492):1197-209.
[2] Roos A, Bakker SJ, Links TP, et al. Thyroid function is associated with components of the metabolic syndrome in euthyroid subjects. Journal of Clinical Endocrinology and Metabolism 2007;92(2):491-6.

[3] De Pergola G, Ciampolillo A, Paolotti S, et al. Free triiodothyronine and thyroid stimulating hormone are directly associated with waist circumference, independently of insulin resistance, metabolic parameters and blood pressure in overweight and obese women. Clinical Endocrinology (Oxf) 2007;67(2):265-9.

[4] Tagliaferri M, Berselli ME, Calo G, et al. Subclinical hypothyroidism in obese patients: relation to resting energy expenditure, serum leptin, body composition and lipid profile. Obese Res 2001;9(3):196-201.

[5] Kitahara CM, Platz EA, Ladenson PW, et al. Body fatness and markers of thyroid function among U.S. men and women. PLoS One 2012;7(4):e34979.

[6] WHO, Obesity: preventing and managing the global epidemic. Report of a WHO Consultation on Obesity, World Health Organisation, Geneva, Switzerland, 1998.

[7] Al-Musa HM. Impact of obesity on serum levels of thyroid hormones among Euthyroid Saudi Adults. Journal of Thyroid Research 2017;2017:5739806.

[8] Knudsen N, Laurberg P, Rasmussen LB, et al. Small differences in thyroid function may be important for body mass index and the occurrence of obesity in the population. J Clin Endocrinol Metab 2005;90(7):401924.

[9] Solanki A, Bansal S, Jindal S, et al. Relationship of serum thyroid stimulating hormone with body mass index in healthy adults. Indian J Endocrinol Metab 2013;17(Suppl 1):S167-9.

[10] Nyrnes A, Jorde R, Sundsfjord J. Serum TSH is positively associated with BMI. Int J Obes (Lond) 2006;30(1):100-5.

[11] Kumar HK, Yadav RK, Prajapati J, et al. Association between thyroid hormones, insulin resistance and metabolic syndrome. Saudi Med J 2009;30(7):907-11.

[12] Chan JL, Heist K, De Paoli AM, et al. The role of falling leptin levels in the neuroendocrine and metabolic adaptation to short term starvation in healthy men. The Journal of Clinical Investigation 2003;111(9):1409-21.

[13] Auwerx J, Staels B. Leptin. Lancet 1998;351(9104):737-42.

[14] Ortiga-Carvalho TM, Oliveira KJ, Soares BA, et al. The role of leptin in regulation of TSH secretion in fed state: in vivo and in vitro studies. J Endocrinol 2002;174(1):121-5.

[15] Aeberli I, Jung A, Murer SB, et al. During rapid weight loss in obese children, reductions in TSH predict improvements in insulin sensitivity independent of changes in body weight or fat. J Clin Endocrinol Metab 2010;95(12):5412-8.

[16] Menendez C, Baldelli R, Camina JP, et al. TSH stimulates leptin secretion by a direct effect on adipocytes. J Endocrinol 2003;176(1):7-12. 
[17] Galofre JC, Pujante P, Abreu C, et al. Relationship between thyroid-stimulating hormone and insulin in euthyroid obese men. Ann Nutr Metab 2008;53(34):188-94.

[18] Makepeace AE, Bremner AP, O'Leary P, et al. Significant inverse relationship between serum free T4 concentration and body mass index in euthyroid subjects: differences between smokers and nonsmokers. Clin Endocrinol (Oxf) 2008;69(4):648-52.

[19] Manji N, Boelaert K, Sheppard MC, et al. Lack of association between serum TSH or free T4 and body mass index in euthyroid subjects. Clin Endocrinology (Oxf) 2006;64(2):125-8.

[20] Alevizaki M, Saltiki K, Voidonikola P, et al. Free thyroxine is an independent predictor of subcutaneous fat in euthyroid individuals. Eur J Endocrinol 2009;161(3):459-65.

[21] Kok P, Roelfsema F, Frolich M, et al. Spontaneous diurnal thyrotropin secretion is enhanced in proportion to circulating leptin in obese premenopausal women. J Clin Endocrinol Metab 2005;90(11):6185-91.

[22] Teixeira PF, Cabral MD, Silva NA, et al. Serum leptin in overt and subclinical hypothyroidism: effect of levothyroxine treatment and relationship to menopausal status and body composition. Thyroid 2009;19(5):443-50.

[23] Choi SH, Lee YJ, Park YJ, et al. Retinol binding protein-4 elevation is associated with serum thyroid-stimulating hormone level independently of obesity in elderly subjects with normal glucose tolerance. J Clin Endocrinol Metab 2008;93(6):2313-8.

[24] Pinkney JH, Goodrick SJ, Katz J, et al. Leptin and the pituitary-thyroid axis: a comparative study in lean, obese, hypothyroid and hyperthyroid subjects. Clin Endocrinol (Oxf) 1998;49(5):583-8.

[25] Ortega E, Pannacciulli N, Bogardus C, et al. Plasma concentrations of free triiodothyronine predict weight change in euthyroid persons. Am J Clin Nutr 2007;85(2):440-5.

[26] Zhang J, Sun H, Chen L, et al. Relationship between serum TSH level with obesity and NAFLD in euthyroid subjects. J Huazhong Univ Sci Technolog Med Sci 2012;32(1):47-52.
[27] Mukherjee S, Mukhopadhyay D, Chakraborty P. Relationship between Body Mass Index (BMI), body fat percent and serum TSH level in euthyroid female subjects. International Journal of Science and Research (IJSR) 2015;4(6):1697-700.

[28] Mihaly E, Fekete C, Tatro JB, et al. Hypophysiotropic thyrotropin-releasing hormone-synthesizing neurons in the human hypothalamus are innervated by neuropeptide $\mathrm{Y}$, agouti related protein, and alphamelanocyte-stimulating hormone. J Clin Endocrinol Metab 2000;85(7):2596-603.

[29] Sorisky A, Bell A, Gagnon A.TSH receptor in adipose cells. Horm Metab Res 2000;32(11-12):468-74.

[30] Valyasevi RW, Harteneck DA, Dutton CM, et al. Stimulation of adipogenesis, peroxisome proliferatoractivated receptor gamma (PPARgamma), and thyrotropin receptor by PPAR gamma agonist in human orbital pre-adipocyte fibroblasts. J Clin Endocrinol Metab 2002;87(5):2352-8.

[31] Betry C, Challan-Belval MA, Bernard A, et al. Increased TSH in obesity: evidence for a BMI independent association with leptin. Diabetes Metab 2015;41(3):248-51.

[32] Bandurskha-Stankiewicz E. Thyroid hormone-obesity and metabolic syndrome. Thyroid Research 2013;6(Suppl 2):A5.

[33] Nannipieri M, Cecchetti F, Anselmino $M$, et al. Expression of thyrotropin and thyroid hormone receptors in adipose tissue of patients with morbid obesity and/or type 2 diabetes: effects of weight loss. Int J Obes (Lond) 2009;33(9):1001-6.

[34] Goodpaster BH, Krishnaswami R, Harris TB, et al. Obesity, regional body fat distribution and the metabolic syndrome in older men and women. Arch Intern Med 2005;165(7):777-83.

[35] Westerink J, Van der Graaf Y, Faber DR, et al. The relation between thyroid-stimulating hormone and measures of adiposity in patients with manifest vascular disease. Eur J Clin Invest 2011;41(2):159-66.

[36] Muscogiuri G, Sorice GP, Mezza T, et al. High-Normal TSH values in obesity: Is it insulin resistance or adipose tissue's guilt? Obesity (Silver Spring) 2013;21(1):101-6. 